\title{
Emotional Challenges across the Welfare provided among the Stranded University Students during Covid-19 Pandemic
}

\author{
Nor Balkish Zakaria1, Juliana Mohd Abdul Kadir², Muhammad Rasyid Abdillah³, \\ Mohd Khairul Ariff Noh ${ }^{4}$, Saunah Zainon 5 \\ 1,5 Faculty of Accountancy, Universiti Teknologi MARA Johor, Malaysia \\ ${ }^{1}$ Accounting Research Institue (ARI), Universiti Teknologi MARA, Selangor \\ ${ }_{2,4}$ Faculty of Business Management, Universiti Teknologi MARA Johor, Malaysia \\ ${ }^{3}$ Department of Management, Universitas Lancang Kuning, Indonesia
}

norbalkish@uitm.edu.my, julia593@uitm.edu.my, m.rasyidabdillah@unilak.ac.id, ariff890@uitm.edu.my, sauna509@uitm.edu.my Tel: 60146332362

\begin{abstract}
The Movement Control Order (MCO) for Covid-19 safety measure caused worry and anxiety among university students, especially those stranded in their university hostels or rental accommodation. Universities' staffs helped their basic living and study needs. This study aims to determine the emotional challenges among these students and examine the association between their emotional score across the university's welfare. Based on a survey of 284 respondents, the findings show that there is a significant difference between their emotions and stranded locations. Residential facilities, information updates, and food provided are substantial to their emotional scores.
\end{abstract}

Keywords: Emotional Challenges; Covid-19 Pandemic; Stranded Students; University Welfare

eISSN: 2398-4287@ 2021. The Authors. Published for AMER ABRA cE-Bs by e-International Publishing House, Ltd., UK. This is an open access article under the CC BYNC-ND license (http://creativecommons.org/licenses/by-nc-nd/4.0/). Peer-review under responsibility of AMER (Association of Malaysian Environment-Behaviour Researchers), ABRA (Association of Behavioural Researchers on Asians/Africans/Arabians) and CE-Bs (Centre for Environment-Behaviour Studies), Faculty of Architecture, Planning \& Surveying, Universiti Teknologi MARA, Malaysia.

DOI: https://doi.org/10.21834/ebpj.v6i16.2719

\subsection{Introduction}

Covid-19 pandemic has caused various types of distresses. When the outbreak formed a sudden contagious wave, in late 2019 in China and other parts of the world while in early 2020 in Malaysia; the Malaysian government as other government across the globe had announced strict control measure to overcome the spread of the disease, which is the movement control order (MCO). This measure has limit people's movement only for their survival necessities, obviously to avoid crowd among communities.

As the Malaysian government first announced MCO on 18th March 2020, the Higher Education of Malaysian Ministry had requested students not to leave their existing residential within 24 hours after the announcement. Hence, many students stranded in the university hostels and their rental accommodation (non-residential) near the campus. This situation had traumatized some students as they feel that they need to be together with their families during this pandemic hardship that rarely happened.

Being away from the family members during a disaster may cause trouble. While overwhelmed with continuous worry, anxiety, and discomfort, the students started to develop emotional distresses along with the MCO as no one is permitted to go anywhere else except the essential services providers. A study reported by Lima et al., (2020) found that emotional distresses and anxiety arose among the

eISSN: 2398-4287C 2021. The Authors. Published for AMER ABRA cE-Bs by e-International Publishing House, Ltd., UK. This is an open access article under the CC BYNC-ND license (http://creativecommons.org/licenses/by-nc-nd/4.0). Peer-review under responsibility of AMER (Association of Malaysian Environment-Behaviour Researchers), ABRA (Association of Behavioural Researchers on Asians/Africans/Arabians) and CE-Bs (Centre for Environment-Behaviour Studies), Faculty of Architecture, Planning \& Surveying, Universiti Teknologi MARA, Malaysia.

DOI: https://doi.org/10.21834/ebpj.v6i16.2719 
population affected by the news media reports and the number of infection cases. Emotional distress including depression, fear, compulsive anxiety, neurasthenia, and hypochondria tend to increase with people experiencing greater perceived stress about the Covid-19 pandemic. Likewise, boredom has been found to affect health and happiness thus causing stronger emotional stress (Yan, Gan, Ding, Wu, \& Duan, 2021).

On the other hand, universities tried their best to serve these students by offering cooked meals, dry rations, health screenings, information updates, counseling, and other necessities. Since such pandemic is very rare based on Malaysia's setting, this study is so essential to highlight few apprehensions matters regarding students' emotional challenges and university welfares during outbreak disaster

However, beginning 27th April 2020, students were started to be sent back to their parents' residential via one of the Malaysian government Covid-19 pandemic initiatives. As of 2nd June 2020, 56,814 students reached their families through this aid (BH Online, 2020). Nevertheless, the potential long-term shock of Covid-19 is existing insights from previous disasters and national predicaments. According to Savage (2020), the SARS global outbreak in 2003 was allied with a 30\% suicide incremental among the elderly over the age of 65 . Approaches like isolation or community quarantine are crucial to minimizing the viral blowout. However, this effort can develop an adverse consciousness impact, such as triggering post-traumatic pressure symptoms, depression, and insomnia. Job loss and financial struggles during this worldwide economic slump have been related to a long-lasting deterioration in mental health. Factually, the unfavorable mental health effects of these catastrophes impact more people and last much longer than the health effects that it might cause.

Therefore, the objective of the present study is twofold. First to determine the emotional challenges among the stranded residential and non-residential students during MCO. Second to examine the significant association between students' emotional challenges across the university's welfares. Could the interest and concern shown by the university able to cope with these students' devastating as more extended depression among these students affect their study motivation? Thus the psychological implication is crystal clear to aid the policymaker and university in handling the utmost welfare during hardship among the students.

This remainder of this paper is divided into few different sections, beginning with the literature review right after this introduction. The methodology section will then be discussed and followed by the findings and discussion. The last section concludes the overall paper.

\subsection{Literature Review}

Theory of Reasoned Action (TRA) is a model for predicting behavioural intention, spanning predictions of attitude and predictions of behaviour. The subsequence separation of behavioural intention from behaviour allows for clarification of limiting factors on attitudinal influence (Martin, James, Andrew, Icek and Loken, 1980). Martin et al. (1980) established a model that led to the study of attitude and behaviour. This research applies the TRA to examine the students' behaviour towards the aids provided by the university to cater for their basic living during a pandemic. At the same time, they are stranded in the university hostels or rental accommodation nearby. The TRA states that the direct forerunner of the students' perception and acceptance towards universities welfare in handling their emotion conflicts while being isolated away from their families during such catastrophe.

University and college students around the world have shown signs of anxiety and stress and to some extent can be a rational response to uncertainty at the time of an outbreak (XiangNg et al., 2020). An epidemic or pandemic outbreak could impact a student's life as these young adults are mostly in their studying period. Residential and non-residential students on campus could be affected in different magnitude. Brooks et al., (2020) reported that $73 \%$ experienced low mood, $7 \%$ anxiety, and $17 \%$ anger, while $5 \%$ felt positive during a lockdown. Similarly, Cao et al., (2020) found that levels of anxiety differed among Chinese college students; ranging from normal (75\%) to mild (21\%), and moderate (3\%) during widespread Covid-19. However, Wang, Xu, Zhao, Cao, He, and Fu (2011) find out that quarantine society does not have immediate adverse psychological effects under an epidemic circumstance. However, the university campus environment poses a high risk of spreading infectious diseases, as it is a mass gathering place for youth (Xu et al., 2011).

According to Lau, Wang, Kim, Gu, Wu, Zhou, and Hao (2016), many students perceived severe consequences if a small outbreak occurred and these young adults believed an outbreak would have a high fatality rate. Besides, Trevors, Muis, Pekrun, Sinatra, and Muijselaar (2017) explore individuals' beliefs about the nature of knowledge and their emotions as potentially interrelated sets of learner characteristics. They posit that wisdom is justified by inquiry-predicted surprise and curiosity, which at times facilitated learning. This is also supported by Spangler, Pekrun, Kramer and Hofman (2002). They find that emotional responses depend on the situation and are co-regulated by stable psychological characteristics, emotional dispositions, and coping abilities. Survivors and contacts of any outbreak and their relations may develop psychological distress (Mohammed, Sheikh, Gidado, Poggensee, Nguku, Olayinka, and Uzoma, 2015). Authorities, especially the university, can play a vital role in teaching contagious disease knowledge and awareness. Stadtlander (2017) suggests a need for a stronger focus on influenza infectious education for undergraduate students by considering these young adults' needs and wants. Health authorities should be well aware of the possible occurrence of psychogenic illness, acknowledge their detailed characteristics, and take its economic burden into account to efficiently mitigate the risk of transmission of infectious diseases (Yang, Kim, Lee, and Park, 2017). This is due to the fact posit by Betancourt, Brennan, Vinck, VanderWeele, Spencer-Walters, Jeong, and Pham (2016) that little attention has been paid to potential relationships between mental health, trauma, and personal exposures to Ebola virus disease and health behaviours in post-conflict.

Research findings within this area will aid in assessing the adequacy of current students' educational curriculum during the disaster. Further insight in designing future multifaceted interventions to promote specific messages to change the attitude and improve practice could also be enabled (Holakouie-Naieni, Ahmadvand, Owais, Assan, Elduma, Jammeh, and Kabir 2015). Lessons could be learned from Ogoina (2016) observation on behavioural and emotional responses to the 2014 Ebola outbreak in Nigeria. The federal and state 
governments, and their local and international partners, ought to respond promptly with a robust and coordinated prevention and control strategy that includes regular dissemination of accurate information and social mobilization.

Upon testing the psychological impact of the Covid-19 pandemic on college students in China, the results of Cao, Fang, Hou, Han, Xu, Dong, and Zheng (2020) indicate that economic effects, and effects on daily life, as well as delays in academic activities, were positively associated with anxiety symptoms. However, social support was negatively correlated with the level of anxiety. Their results suggest that college student's mental health should be monitored during the disaster. Hence, psychosocial support may be needed for people with outbreak experiences. Preventing, detecting, and responding to mental health conditions should be an essential component of global health security efforts (Jalloh, Li, Bunnell, Ethier, O'Leary, Hageman, and Marston, 2018). Hence, this study hypothesizes that: $H_{1}$ : There is a significant difference in the emotional challenge between residential and non-residential students.

$H_{2}$ : There is a significant association between stranded students' emotional challenges and welfare provided by the university.

\subsection{Methodology}

A census study was mapped out among 284 residential students and non-residential who were identified as stranded among Universiti Teknologi MARA (UiTM) Johor students across two campuses; Segamat and Pasir Gudang. A set of google form questionnaires were developed consisting of respondents' background, emotion scores, and responses to each category of six categories of welfares provided by the university - general welfare perception, health, residential, information, food, and counseling.

A census study was mapped out among 284 residential students and non-residential who were identified as stranded among Universiti Teknologi MARA (UiTM) Johor students across two campuses; Segamat and Pasir Gudang. A set of google form questionnaires were developed consisting of respondents' background, emotion scores, and responses to each category of six categories of welfares provided by the university - general welfare perception, health, residential, information, food, and counseling.

Four (4) items were constructed for general welfare perception; four (4) items were constructed for health; three (3) items were constructed for residential; three (3) items were constructed for information; four (4) items were constructed for food; three (3) items were constructed for counseling. 5 Likert scale scores were developed for each item - not satisfied (1); less satisfied (2); neutral (3); satisfied (4); very satisfied (5). While to understand the probability of students' emotions, eight items were created for emotional measurement, and the answers for this are - not stressful (1); less stressful (2); neutral (3); stressful (4); very stressful (5).

Besides the descriptive data collected, univariate (simple t-test) and multivariate tests (multiple regression) were conducted to analyze the $\mathrm{H}_{1}$ and $\mathrm{H}_{2}$ of the study.

\subsection{Findings}

\section{Descriptive Results}

Table 1 presents the results of the whole parameter respondents. For gender, more than half $(67.3 \%)$ of the respondents are female. $69 \%$ of the respondents came from M40 (medium income) category with an average household income between RM4, 501 to RM8, 499.

Almost two-thirds of the students were stranded in university hostels $(71.5 \%)$. More than half of the respondents were emotionally stressed (36.6\%) and very stressed (39.4\%). None of the respondents feels not stressful at all. $68.3 \%$ of the respondents perceived satisfaction with the university's general welfare. $53.5 \%$ of the students feel happy with the university's health facilities, while $28.6 \%$ feel very satisfied. More than half of the respondents think pleased $(41.55 \%)$ and delighted $(26.7 \%)$ with the university's residential facilities. $40.1 \%$ of the respondents satisfied with the information provided to them by the university during their stay. More than half (58.8\%) of the respondents helped with the university's food supplied to them. $30.9 \%$ of the respondents satisfied with the counseling services offered to them, while $15.1 \%$ and $25 \%$ feel not satisfied and less satisfied. This may not be a surprise since young adults are quite reluctant to meet with professionals to discuss any emotional problem they suffer, yet peers are more preferred (Geldard, Geldard and Foo, 2019).

Table 1: Respondents' Descriptive Results, N=284

\begin{tabular}{clcc}
\hline & Details & No & $\%$ \\
\hline \multirow{2}{*}{ Gender } & 1-Male & 93 & 32.7 \\
& 2-Female & 191 & 67.3 \\
\hline \multirow{2}{*}{ Household Income } & 1-Above RM8,500 & 32 & 11.2 \\
& 2-Between RM4,501-RM8,499 & 198 & 69.7 \\
& 3-Below RM4,500 & 54 & 19 \\
\hline \multirow{2}{*}{ Stranded location } & 1-University hostels & 203 & 71.5 \\
\hline \multirow{2}{*}{ Emotional } & 2-Rental accommodation & 81 & 28.5 \\
\hline
\end{tabular}




\begin{tabular}{|c|c|c|c|}
\hline & 3-Neutral & 63 & 22.2 \\
\hline & 4-Stressful & 104 & 36.6 \\
\hline & 5 -Very stressful & 112 & 39.4 \\
\hline \multirow{5}{*}{ General welfare perception } & 1-Not satisfied & 6 & 2.1 \\
\hline & 2-Less satisfied & 12 & 4.2 \\
\hline & 3-Neutral & 39 & 13.7 \\
\hline & 4-Satisfied & 194 & 68.3 \\
\hline & 5-Very satisfied & 33 & 11.6 \\
\hline \multirow{5}{*}{ Health } & 1-Not satisfied & 5 & 1.7 \\
\hline & 2-Less satisfied & 19 & 6.7 \\
\hline & 3-Neutral & 27 & 9.5 \\
\hline & 4-Satisfied & 152 & 53.5 \\
\hline & 5-Very satisfied & 81 & 28.6 \\
\hline \multirow{5}{*}{ Residential } & 1-Not satisfied & 12 & 4.2 \\
\hline & 2-Less satisfied & 31 & 10.9 \\
\hline & 3-Neutral & 47 & 16.5 \\
\hline & 4-Satisfied & 118 & 41.5 \\
\hline & 5-Very satisfied & 76 & 26.7 \\
\hline \multirow{5}{*}{ Information } & 1-Not satisfied & 29 & 10.2 \\
\hline & 2-Less satisfied & 39 & 13.7 \\
\hline & 3-Neutral & 41 & 14.4 \\
\hline & 4-Satisfied & 114 & 40.1 \\
\hline & 5-Very satisfied & 61 & 21.5 \\
\hline \multirow{5}{*}{ Food } & 1-Not satisfied & 12 & 4.2 \\
\hline & 2-Less satisfied & 28 & 9.9 \\
\hline & 3-Neutral & 39 & 13.7 \\
\hline & 4-Satisfied & 167 & 58.8 \\
\hline & 5-Very satisfied & 38 & 13.4 \\
\hline \multirow{5}{*}{ Counselling } & 1-Not satisfied & 43 & 15.1 \\
\hline & 2-Less satisfied & 71 & 25 \\
\hline & 3-Neutral & 58 & 20.4 \\
\hline & 4-Satisfied & 88 & 30.9 \\
\hline & 5-Very satisfied & 24 & 8.5 \\
\hline
\end{tabular}

\section{Univariate test}

A simple T-test was conducted between the students who stay in university hostels (residential) and rental accommodation (nonresidential) to see any significant difference within their emotional score. Based on the two-tail format, the p-value reported is 0.093 and, therefore, the emotional difference between the residential students and non-residential students is statistically significantly different from zero at a $95 \%$ level of significance. There is sufficient evidence $(p=0.03)$ to suggest that it is significantly different in these two groups of students' emotions. Hence, $\mathrm{H}_{1}$ : there is a significant difference in the emotion challenge between residential and nonresidential students is supported.

\section{Multiple Regression Results among variables}

A regression analysis was performed to examine further the significant association between stranded students' emotional challenges and welfare provided by the university while controlling the effect of respondents' demographic - gender and household income.

Table 2 depicts the results of the regression analysis. The results show that respondents' emotional score is significant to the residential facilities, information, and food. The university's residential facilities are positively significant to respondents' emotional score at $95 \%$ confidence level. In comparison, the university's information is also positively significant to their emotion at a $99 \%$ confidence level. Additionally, the better and steady emotion was also significantly associated with the satisfaction level of food supplies by the university at a $99 \%$ confidence level. 
Table 2: Multiple Regression Results among the Independent and Control Variables

\begin{tabular}{cccc}
\hline & Coefficients & T-stat & VIF \\
\hline Emotional score & & & 1.105 \\
\hline Welfare Perception & -0.029 & -0.411 & 1.118 \\
\hline Health & -0.025 & -0.64 & 1.165 \\
\hline Residential & 0.158 & $2.018^{* \star}$ & 1.278 \\
\hline Information & 0.209 & $2.356^{\star \star *}$ & 1.167 \\
\hline Food & 0.212 & $2.416^{* \star *}$ & 1.167 \\
\hline Counselling & -0.029 & -0.8 & 1.165 \\
\hline Gender & 0.163 & $2.131^{* *}$ & 1.283 \\
\hline Household Income & 0.231 & $2.857^{* \star *}$ & 1.24 \\
\hline Note: ${ }^{* * *}$ significant at $99 \%$ and ${ }^{* *}$ significant at $95 \%$ &
\end{tabular}

Thus, the results accepted $\mathrm{H}_{2}$ : there is a significant association between stranded students' emotional challenges and welfare provided by the university whenever the interest is measured by the residential facilities provided, the information supplied and food served to them. Based on the control variable, the results imply that the higher the household income, the lower score the emotional among respondents. This could due to the comfort expectation that these respondents may anticipate during the pandemic outbreak in their stranded locations. Female respondents are more emotionally fragile to the pandemic turmoil. Variance inflation factor (VIF) results show no multicollinearity problem suspected in this research parameter.

\subsection{Discussion}

While students' emotional challenges can be influenced by many factors related to the TRA, it is interesting to note that emotional challenges play an essential role during MCO. Table 1 shows that the students stranded at the university are mostly women. It causes worry, anxiety, and discomfort among varsity students, especially those stranded in their residential campus (hostel) or rented (nonresidential) students' accommodation. The findings in this study conform to Xu et al. (2011) on the importance of a campus environment with a high risk of infectious diseases. The American College of Health Association and the World Health Organization (WHO) report that increased psychological stress and mental disorders are common among college students even during college or university semester breaks (Auerbach et al., 2016). Therefore, this quarantine time makes them feel emotionally unhappy because they are away from family and cannot predict when the pandemic will end.

As shown in Table 2, the information provided and the food served to have the highest effect on students' emotional challenges. Out of the aids provided by the university, residential, information, and food are positively significant to affect their emotions. Spangler's (2002) study also showed that other situations and psychological characteristics were correlated with emotional responses, especially to those who are stranded during an unexpected phenomenon. While another variable such as counseling would be necessary, it is less significant. This may be due to unnecessary counseling during the initial stage of the outbreak. These stranded students can still manage their mental and emotional quite well. However, a counselor should be prepared to deal with any problems, when clients seek professional psychological health services during a more extended crisis related to Covid-19.

\subsection{Conclusion and Recommendations}

The purpose of this study is to examine the emotional challenges among the residential and non-residential stranded university students and to examine further the significant association between their emotional challenges towards the university's welfare. This study's parameters also control the effect of gender and household income.

Engaging TRA highlights the student's indication of their perception and acknowledgment towards university assistances while managing their emotion for being isolated away from their families during such pandemic catastrophe. Some students struggle to calm themselves down and refocus to continue to study. As this pandemic is rare and not often, almost no one is mentally and physically prepared. On the other hand, universities try to provide help in many forms to comfort and fulfill these stranded students' basic needs. Therefore, this study was designed to gather information on how well the university's welfare was able to ease the worrying among these stranded students. The welfares were categorized as health checks, residential facilities, information updates, food served, and counseling. Gender and household income were controlled in testing the parameter.

The study results show that the emotional difference between residential students and non-residential students is statistically significant. Moreover, the residential facilities provided, the information supplied, and the food served is substantial to the stranded students' emotions during the pandemic. Based on the control variable, the results imply that the higher household income, the lower score the emotional among respondents. This could due to the comfort expectation that these respondents may anticipate during the pandemic outbreak in their stranded locations. Female respondents and higher household income as control variables among the respondents also significantly affected emotion. 
This study's results could pave the way for universities and other researchers to further explore the ultimate welfare that any students acknowledge during any disaster, especially whenever they are apart from other family members. The aspect of interest during hardship may vary from one disaster to another. Despite the findings serve in the study, the limitation of data collected was only gained in a public university in Malaysia which is University Teknologi MARA, Johor branch. Perhaps future researchers could anticipate developing a model that scrutinizes welfare types based on different traumatize with larger sampling frames across countries.

\section{Acknowledgement}

This research was funded by Universiti Teknologi MARA, Johor, Malaysia, under the Bestari phase 1/2020 research grant.

\section{Paper Contribution to Related Field of Study}

This paper added to the existing literature on the study of emotion challenges between residential and non-residential students. It also examines the association between stranded students' emotional challenges and welfare provided by the university. The research shows that the respondents were emotionally affected by this rare and unexpected pandemic phenomenon. Nonetheless, the university's interest has helped them be less traumatized.

\section{References}

Auerbach, R. P., Alonso, J., Axinn, W. G., Cuijpers, P., Ebert, D. D., Green, J. G., \& Bruffaerts, R. (2016). Mental Disorders Among College Students in The World Health Organization World Mental Health Surveys. Psychological Medicine, 46(14), 2955-2970.

Betancourt, T. S., Brennan, R. T., Vinck, P., VanderWeele, T. J., Spencer-Walters, D., Jeong, J, \& Pham, P. (2016). Associations between Mental Health and EbolaRelated Health Behaviors: A Regionally Representative Cross-Sectional Survey in Post-Conflict Sierra Leone. PLoS medicine, 13(8).

BH online (2020) retrieved from http://bhnews@bh.com.my as at 10th January 2021.

Brooks, S. K., Webster, R. K., Smith, L. E., Woodland, L., Wessely, S., Greenberg, N., \& Rubin, G. J. (2020). The Psychological Impact of Quarantine and How to Reduce It: Rapid Review of the Evidence. The Lancet, 395(10227), 912-920.

Cao, W., Fang, Z., Hou, G., Han, M., Xu, X., Dong, J., \& Zheng, J. (2020). The psychological impact of the COVID-19 epidemic on college students in China. Psychiatry research, 287, 112934 .

Geldard, K., Geldard, D., \& Foo, R. Y. (2019). Counselling Adolescents: The Proactive Approach for Young People. Sage

Holakouie-Naieni, K., Ahmadvand, A., Owais, R. A. Z. A., Assan, A., Elduma, A. H., Jammeh, A., \& Kabir O., R. A. S. (2015). Assessing The Knowledge, Attitudes, and Practices of Students Regarding Ebola Virus Disease Outbreak. Iranian Journal of Public Health, 44(12), 1670.

Jalloh, M. F., Li, W., Bunnell, R. E., Ethier, K. A., O'Leary, A., Hageman, K. M., \& Marston, B. J. (2018). Impact of Ebola Experiences and Risk Perceptions on Mental Health in Sierra Leone, July 2015. BMJ Global Health, 3(2), E000471.

Lau, J. T., Wang, Z., Kim, Y., Gu, J., Wu, A. M., Zhou, Q., \& Hao, Y. (2016). Anticipated Negative Responses By Students To Possible Ebola Virus Outbreak, Guangzhou, China. Emerging Infectious Diseases, 22(1), 154.

Lima, C. K. T., de Medeiros Carvalho, P. M., Lima, I. D. A. A. S., de Oliveira Nunes, J. V. A., Saraiva, J. S., de Souza, R. I., \& Neto, M. L. R. (2020). The Emotional Impact of Coronavirus 2019-nCoV (new Coronavirus disease). Psychiatry Research, 287, 112915.

Martin, F., James, J., Andrew, R., Icek, A., \& Loken, B. (1980). Predicting and Understanding Family Planning Behaviors: Beliefs, Attitudes, and Intentions. Understanding Attitudes and Predicting Social Behavior. Englewood Cliffs, NJ: Prentice-Hall.

Mohammed, A., Sheikh, T. L., Gidado, S., Poggensee, G., Nguku, P., Olayinka, A., \& Uzoma, O. (2015). An Evaluation of Psychological Distress and Social Support of Survivors and Contacts of Ebola Virus Disease Infection and Their Relatives in Lagos, Nigeria: A Cross Sectional Study- 2014. BMC Public Health, $15(1), 824$.

Ng, Q. X., De Deyn, M. L. Z. Q., Loke, W., \& Chan, H. W. (2020). A framework to deal with uncertainty in the age of CoVID-19. Asian Journal of Psychiatry, 54, 102263102263.

Ogoina, D. (2016). Behavioural and Emotional Responses to the 2014 Ebola Outbreak in Nigeria: A Narrative Review. International Health, 8(1), 5-12.

Savage, M. (2020). Covid-19 has increased anxiety for many of us, and experts warn a sizable minority could be left with mental health problems that outlast the pandemic. Retrived from https://www.bbc.com/worklife/article/20201021-coronavirus-the-possible-long-term-mental-health-impacts on 17th February 2021.

Spangler, G., Pekrun, R., Kramer, K., \& Hofmann, H. (2002). Students' Emotions, Physiological Reactions, and Coping in Academic Exams. Anxiety, Stress \& Coping, 15(4), 413-432.

Stadtlander, C. T. H. (2017). A Mixed-Methods Normative Case Study of Undergraduate Students' Attitudes and Behaviors towards Influenza and Vaccination in the Post2009 Influenza A (H1N1) Pandemic Era. 
Trevors, G. J., Muis, K. R., Pekrun, R., Sinatra, G. M., \& Muijselaar, M. M. (2017). Exploring the Relations between Epistemic Beliefs, Emotions, and Learning from Texts. Contemporary Educational Psychology, 48, 116-132.

Wang, Y., Xu, B., Zhao, G., Cao, R., He, X., \& Fu, S. (2011). Is Quarantine Related To Immediate Negative Psychological Consequences During The 2009 H1N1 Epidemic? General Hospital Psychiatry, 33(1), 75-77.

Xu, J., Zheng, Y., Wang, M., Zhao, J., Zhan, Q., Fu, M., \& Cheng, Y. (2011). Predictors of Symptoms of Posttraumatic Stress in Chinese University Students during the 2009 H1N1 Influenza Pandemic. Medical Science Monitor: International Medical Journal of Experimental and Clinical Research, 17(7).

Yan, L., Gan, Y., Ding, X., Wu, J., \& Duan, H. (2021). The relationship between perceived stress and emotional distress during the COVID-19 outbreak: Effects of Boredom Proneness and Coping Style. Journal of Anxiety Disorders, 77, 102328.

Yang, T. U., Kim, H. J., Lee, Y. K., \& Park, Y. J. (2017). Psychogenic Illness Following Vaccination: Exploratory Study Of Mass Vaccination Against Pandemic Influenza A (H1N1) In 2009 In South Korea. Clinical and Experimental Vaccine Research, 6(1), 31-37. 